\title{
Factors affecting pre-weaning kid mortality in South African Angora goats
}

\author{
M.A. Snyman ${ }^{\#}$ \\ Grootfontein Agricultural Development Institute, Private Bag X529, Middelburg (EC) 5900, South Africa
}

\begin{abstract}
The data used for this study were collected in 12 different Angora goat studs from 2000 to 2004. Data collected on 17534 kids born alive in the different studs were included in the analyses. Average pre-weaning mortality rate was $11.5 \%$ and ranged from $8.6 \%$ to $16.5 \%$ (of the 17534 kids born alive, 2018 kids died between birth and weaning at four months of age). Mortality rate in male kids was higher than that recorded for female kids (11.9\% vs. 11.1\%). When comparing the management systems followed from mating up until weaning in the different studs with the corresponding pre-weaning mortality rates, it is obvious that there was no discernible trend. Of the 2018 deaths recorded, the probable cause for only 601 (29.8\%) deaths was known. The most important problems were predators, small, unthrifty kids who needed help with suckling, does having little or no milk and does abandoning their kids. When combining the latter three causes with udder problems (3.5\%), 35.7\% of pre-weaning mortalities was due to these causes. Birth weight and sex of the kid had a significant influence on pre-weaning mortality rate. Single-born kids had the lowest mortality rate (10\%), followed by twin-born (13\%) and triplet-born (22\%) kids. Despite large differences in mortality rate recorded between sires within flocks, a heritability of $0.04 \pm 0.01$ was estimated for pre-weaning mortality rate. This low overall heritability could be attributed to the fact that causes of mortality differed considerably among kids and many of these causes may have no genetic background.
\end{abstract}

Keywords: Rearing environment, reproduction, weaning, birth weight

"\#-mail: grethasn@daff.gov.za

\section{Introduction}

Reproduction and kid survival rate are the most important traits influencing income in Angora goats. High reproductive and kid survival rates will ensure a large proportion of the more expensive kid and young goat mohair in the clip, and will also contribute to higher selection intensity. The poor reproductive performance and high kid mortality rate of Angora goats are well documented (Terblanché, 1988; Geyer, 1998; Snyman, 2010). Factors that may be implicated in the survival rate of kids include birth weight of the kid, genetics, mothering ability and milk production of the dam, adverse environmental or feeding conditions, diseases and predators.

Very little work on mortality rate in goats, especially Angora goats, has been published to date (Van der Westhuizen, 1980; Terblanché, 1988; Husain et al., 1995; Geyer, 1998; Perez-Razo et al., 1998; Awemu et al., 1999, Turkson, 2003). These authors cited losses of 10 to 30\%. Similar losses occur in sheep, and considerable research effort has focused on investigating possible causes of lamb mortality (Alexander, 1984; Rook et al., 1990; Haughey, 1991; Morris et al., 2000; Mukasa-Mugerwa, 2000; Turkson, 2003; Southey, 2004; Turkson \& Sualisu, 2005; Mandal et al., 2007; Dwyer, 2008; Everett-Hincks. \& Dodds, 2008). The difference between sheep and Angora goats is that very little losses occur in sheep lambs after weaning, whereas kid mortality could be as high as $15 \%$ from weaning till 18 months of age (recorded for the Jansenville experimental flocks over a 10-year period).

A study was done on 12 Angora goat studs with the objectives of firstly, to quantify the extent of kid mortalities, secondly to identify the major causes of mortality, thirdly to determine if management practices influence kid mortality rate and fourthly to quantify the effect of certain known variables on mortality rate.

\section{Material and Methods}

The data used for this study were collected during a project that involved an investigation into reproductive performance and kid mortality aspects in South African Angora goats. This study was conducted from 2000 to 2004 in 12 Angora goat studs, kept under different management systems. 
Data collected during the kidding seasons included the following information for each kid: Kid identity, dam identity (46 unknown), sire identity (4279 unknown), birth date, birth weight, sex, birth and rearing status, rearing group and weaning weight. Does that failed to kid, aborted or delivered stillborn kids, needed help with kidding, had udder defects, or kids that needed help with suckling, were also recorded. Furthermore, probable cause of death was recorded where possible. Data collected on 17534 kids born alive in the different studs were included in the analyses. The following model was fitted to the data to estimate least squares means for survival rate:

$\mathrm{Y}_{\mathrm{ijklm}}=\mu+\mathrm{h}_{\mathrm{i}}+\mathrm{j}_{\mathrm{j}}+\mathrm{s}_{\mathrm{k}}+\mathrm{b}_{\mathrm{l}}+(\mathrm{hs})_{\mathrm{ik}}+(\mathrm{js})_{\mathrm{jk}} \mathrm{e}_{\mathrm{ijklm}}$

Where

$Y_{\mathrm{ijklm}}=$ trait of the m'th animal of the l'th birth status of the k'th sex of the j'th birth-year of the i'th stud;

$\mu=$ overall mean;

$\mathrm{h}_{\mathrm{i}}=$ fixed effect of the i'th stud;

$\mathrm{j}_{\mathrm{j}}=$ fixed effect of the j'th birth-year;

$s_{k}=$ fixed effect of the k'th sex;

$\mathrm{b}_{\mathrm{l}}$ = fixed effect of the l'th birth status;

$(\mathrm{hs})_{\mathrm{ik}}=$ effect of the interaction between the i'th stud and the k'th sex;

$(\mathrm{js})_{\mathrm{jk}}=$ effect of the interaction between the j'th birth-year and the k'th sex;

$\mathrm{e}_{\mathrm{ijk} k \mathrm{~m}}=$ random error with zero mean and variance $\mathrm{I}^{2}{ }_{\mathrm{e}}$.

To determine the effect of management system on survival rate, the fixed effect for stud was replaced with a fixed effect for management system in the above model. A regression analysis was performed to obtain the relationship between birth weight and survival rate of kids. For this purpose, birth weights of kids were divided into weight classes. Weight class was included in the above model to obtain least squares means for the different weight classes. Kid survival rate was subsequently regressed on these weight class least squares means.

\section{Results and Discussion}

Survival rate from birth to weaning is summarised in Table 1 for data collected from 2000 to 2004 . Average pre-weaning survival rate was $88.5 \pm 0.89$ and ranged from $79.6 \pm 1.00 \%$ to $87.2 \pm 0.92 \%$ among years (of the 17534 kids born alive, 2018 kids died between birth and weaning at four months of age). There was no significant difference in survival rate between ram and doe kids $(84.0 \pm 0.89$ vs. $84.9 \pm 0.89)$.

Table 1 Pre-weaning survival rate ( \pm s.e.) of ram and doe kids over the survey period

\begin{tabular}{|c|c|c|c|c|c|c|c|c|c|}
\hline \multirow[b]{2}{*}{ Year } & \multicolumn{3}{|c|}{ All kids } & \multicolumn{3}{|c|}{ Ram kids } & \multicolumn{3}{|c|}{ Doe kids } \\
\hline & $\begin{array}{l}\text { Kids } \\
\text { born }\end{array}$ & $\begin{array}{l}\text { Kids } \\
\text { died }\end{array}$ & Survival rate (\%) & $\begin{array}{l}\text { Kids } \\
\text { born }\end{array}$ & $\begin{array}{l}\text { Kids } \\
\text { died }\end{array}$ & $\begin{array}{c}\text { Survival rate } \\
(\%)\end{array}$ & $\begin{array}{l}\text { Kids } \\
\text { born }\end{array}$ & $\begin{array}{l}\text { Kids } \\
\text { died }\end{array}$ & $\begin{array}{c}\text { Survival rate } \\
(\%)\end{array}$ \\
\hline 2000 & 3087 & 327 & $85.7^{\mathrm{a}} \pm 1.00$ & 1565 & 181 & $84.5 \pm 1.17$ & 1522 & 146 & $86.8 \pm 1.19$ \\
\hline 2001 & 3229 & 364 & $85.3^{b} \pm 0.98$ & 1679 & 179 & $86.3 \pm 1.14$ & 1550 & 185 & $84.4 \pm 1.16$ \\
\hline 2002 & 4352 & 376 & $87.2^{\mathrm{c}} \pm 0.92$ & 2200 & 182 & $87.7 \pm 1.05$ & 2152 & 194 & $86.8 \pm 1.05$ \\
\hline 2003 & 4000 & 478 & $84.5^{c} \pm 0.93$ & 2007 & 255 & $83.6 \pm 1.09$ & 1993 & 223 & $85.3 \pm 1.09$ \\
\hline 2004 & 2866 & 473 & $79.6^{\mathrm{abc}} \pm 1.00$ & 1428 & 257 & $78.2 \pm 1.20$ & 1438 & 216 & $81.1 \pm 1.21$ \\
\hline $\begin{array}{c}\text { Total / } \\
\text { Average }\end{array}$ & 17534 & 2018 & $88.5 \pm 0.89$ & 8879 & 1054 & $84.0 \pm 0.89$ & 8655 & 964 & $84.9 \pm 0.89$ \\
\hline
\end{tabular}

abc Means within columns with the same superscripts differ significantly $(\mathrm{P}<0.01)$. 
Table 2 Pre-weaning survival rate ( \pm s.e.) of ram and doe kids in the different studs

\begin{tabular}{cccccc}
\hline \multirow{2}{*}{ Stud } & \multirow{2}{*}{$\begin{array}{c}\text { Number of kids } \\
\text { born }\end{array}$} & $\begin{array}{c}\text { Number of kids } \\
\text { died }\end{array}$ & All kids & Ram kids & Doe kids \\
\cline { 4 - 5 } & & & & & \\
1 & 833 & 25 & $93.2 \pm 1.34$ & $93.2 \pm 1.74$ & $93.4 \pm 1.71$ \\
2 & 2055 & 177 & $83.9 \pm 1.00$ & $84.3 \pm 1.23$ & $83.4 \pm 1.21$ \\
3 & 1542 & 108 & $85.9 \pm 1.21$ & $86.7 \pm 1.51$ & $85.1 \pm 1.55$ \\
4 & 1168 & 378 & $81.3 \pm 0.98$ & $80.1 \pm 1.16$ & $82.6 \pm 1.17$ \\
5 & 2506 & 95 & $86.4 \pm 1.23$ & $84.7 \pm 1.52$ & $88.1 \pm 1.60$ \\
6 & 1140 & 114 & $78.4 \pm 1.46$ & $78.5 \pm 1.89$ & $78.4 \pm 1.93$ \\
7 & 666 & 164 & $80.1 \pm 1.26$ & $80.3 \pm 1.60$ & $79.9 \pm 1.61$ \\
8 & 1017 & 367 & $87.0 \pm 0.93$ & $87.0 \pm 1.07$ & $86.9 \pm 1.07$ \\
9 & 3752 & 18 & $82.2 \pm 2.58$ & $82.7 \pm 3.54$ & $81.8 \pm 3.58$ \\
10 & 172 & 166 & $85.8 \pm 1.12$ & $85.4 \pm 1.38$ & $86.1 \pm 1.41$ \\
11 & 1515 & 133 & $86.1 \pm 1.19$ & $83.2 \pm 1.52$ & $89.1 \pm 1.51$ \\
12 & 1168 & & & & \\
\hline
\end{tabular}

This is in contrast with the findings of Perez-Razo et al. (1998). Pre-weaning survival rates for kids in the different studs are presented in Table 2. There was a large variation in kid survival rate among the different studs ( $\mathrm{P}<0.01)$, ranging from $78.4 \pm 1.46 \%$ to $93.2 \pm 1.34 \%$.

Management system (MS) (Table 3) had an overall significant effect on survival rate $(\mathrm{P}<0.01)$ and significant differences were observed among most of the management systems (Table 3). The exceptions were that MS2 did not differ from MS3 and MS6; MS3 did not differ from MS 6; MS4 did not differ from MS6, MS7 or MS8; and there were no differences among MS5, MS6, MS7 and MS8.

However, when comparing the management systems followed from mating up to weaning in the different studs with the corresponding pre-weaning survival rate, it is obvious that there was no discernible trend. For example, Stud 1 with the highest survival rate and Studs 7 and 8 with the lowest rates had the same general management practices, all providing none or the minimum additional feeding. Other factors not considered in the specific model therefore accounted for these differences.

During the last six weeks of pregnancy, foetal growth increases rapidly with the consequence that the nutritional requirements at that stage are almost double that of a dry doe. Nutritional requirements of a doe suckling twins, is almost three times higher than that of a dry doe. In a study by Jordan \& Le Feuvre (1989), mortality rates due to starvation, mismothering and desertion were higher in does fed a below maintenance diet than in does fed an above maintenance diet. Furthermore, more lamb deaths were due to starvation in a group of does with unsound udders than in a sound udder group. Van der Westhuizen (1980) reported kid mortalities in four groups of Angora does receiving either high/low protein/energy diets during the last six weeks of pregnancy. Mortality rates of $8 \%, 83 \%, 42 \%$ and $100 \%$ were recorded for does that received high/high, high/low, low/high and low/low protein/energy diets, respectively.

The does in most studs did not receive any supplementary feeding during pregnancy. The exceptions were the does in Studs 5, 9 and 11 that were supplemented with energy blocks during the third trimester of pregnancy and those does in Stud 12 that were run on pastures for the duration of pregnancy. However, kid mortality rates were not lower in the latter studs, compared to those studs where the does did not receive any supplementation. 
Table 3 Management systems (MS) and average survival rate per system followed in the various studs

\begin{tabular}{|c|c|c|c|c|c|}
\hline \multirow{2}{*}{$\begin{array}{l}\text { MS } \\
\text { (Stud) }\end{array}$} & \multirow{2}{*}{$\begin{array}{l}\text { Survival } \\
\text { rate }\end{array}$} & \multicolumn{4}{|c|}{ Management practices } \\
\hline & & Before mating & During pregnancy & During kidding & During lactation \\
\hline $\begin{array}{c}1 \\
(1)\end{array}$ & $97.0 \pm 1.10$ & $\begin{array}{l}\text { Does on veld, no } \\
\text { supplementation }\end{array}$ & $\begin{array}{l}\text { Does on veld, no } \\
\text { supplementation }\end{array}$ & $\begin{array}{l}\text { Does kid in veld, no } \\
\text { supplementation }\end{array}$ & $\begin{array}{l}\text { Does on veld, some } \\
\text { years supplemented } \\
\text { with chocolate grain* }\end{array}$ \\
\hline $\begin{array}{c}2 \\
(7,8)\end{array}$ & $83.5 \pm 0.77$ & $\begin{array}{l}\text { Does on veld, no } \\
\text { supplementation }\end{array}$ & $\begin{array}{l}\text { Does on veld, no } \\
\text { supplementation }\end{array}$ & $\begin{array}{l}\text { Does kid in veld, no } \\
\text { supplementation }\end{array}$ & $\begin{array}{l}\text { Does on veld, some } \\
\text { years supplemented } \\
\text { with chocolate grain }\end{array}$ \\
\hline $\begin{array}{c}3 \\
(5)\end{array}$ & $84.9 \pm 0.63$ & $\begin{array}{l}\text { Does on veld, no } \\
\text { supplementation }\end{array}$ & $\begin{array}{l}\text { Does } \\
\text { supplemented with } \\
\text { energy blocks } \\
\text { third trimester of } \\
\text { pregnancy }\end{array}$ & $\begin{array}{l}\text { Does kid on pastures } \\
\text { and in veld }\end{array}$ & $\begin{array}{l}\text { Does on veld, some } \\
\text { years supplemented } \\
\text { with feed pellets / } \\
\text { blocks }\end{array}$ \\
\hline $\begin{array}{c}4 \\
(6)\end{array}$ & $91.7 \pm 0.94$ & $\begin{array}{l}\text { Does on veld, no } \\
\text { supplementation }\end{array}$ & $\begin{array}{l}\text { Does on veld, no } \\
\text { supplementation }\end{array}$ & $\begin{array}{l}\text { Does kid in veld and } \\
\text { on pastures }\end{array}$ & $\begin{array}{l}\text { Does on veld, some } \\
\text { years supplemented } \\
\text { with chocolate grain }\end{array}$ \\
\hline $\begin{array}{c}5 \\
(2,3,4)\end{array}$ & $88.3 \pm 0.46$ & $\begin{array}{l}\text { Does on veld, no } \\
\text { supplementation }\end{array}$ & $\begin{array}{l}\text { Does on veld, no } \\
\text { supplementation }\end{array}$ & Does kid on pastures & $\begin{array}{l}\text { Does on veld, some } \\
\text { years supplemented } \\
\text { with chocolate grain }\end{array}$ \\
\hline $\begin{array}{c}6 \\
(10)\end{array}$ & $89.5 \pm 2.42$ & $\begin{array}{l}\text { Does on veld, no } \\
\text { supplementation }\end{array}$ & $\begin{array}{l}\text { Does on veld, no } \\
\text { supplementation }\end{array}$ & $\begin{array}{l}\text { Does kid on pastures } \\
\text { and in veld }\end{array}$ & $\begin{array}{l}\text { Does on veld, some } \\
\text { years supplemented } \\
\text { with chocolate grain }\end{array}$ \\
\hline $\begin{array}{c}7 \\
(9,11)\end{array}$ & $89.9 \pm 0.44$ & Flushing of does & $\begin{array}{l}\text { Does } \\
\text { supplemented with } \\
\text { energy blocks } \\
\text { third trimester of } \\
\text { pregnancy }\end{array}$ & Does kid on pastures & $\begin{array}{l}\text { Does on veld, some } \\
\text { years supplemented } \\
\text { with feed pellets }\end{array}$ \\
\hline $\begin{array}{c}8 \\
(12)\end{array}$ & $88.6 \pm 0.93$ & Does on pastures & Does on pastures & Does kid on pastures & Does on pastures \\
\hline
\end{tabular}

* Alkali-ionophore-treated grain.

Causes of kid mortalities from birth to weaning are summarised in Table 4 for the data collected from 2000 to 2004. Of the 2018 deaths recorded, the probable cause for 601 (29.8\%) is known. When estimating the relative importance of the various causes, only data from these 601 kids were used, and the contribution of each cause was expressed relative to the number of deaths and not relative to the number of kids born. From these, mortality rates due to the various causes were calculated on a flock basis, expressed as number of kids that died per 100 kids that were born alive, assuming that the causes of death for the 1417 kids without known causes of death are similar to those with known causes of death.

The most important problems were predators (39.1\%), small, unthrifty kids which needed help with suckling (18.6\%), does having little or no milk (6.8\%) and does abandoning their kids (6.8\%). When combining the latter three causes with udder problems (3.5\%), 35.7\% of pre-weaning mortalities were due to these causes.

The causes of kid mortalities indicated in Table 4 can also be classified into the following categories, namely causes with a genetic basis (C3, C4, C10), causes which could be addressed through the application of relevant management practices (C1, C2, C4, C6, C8, C9, C11), reasons to which the dam contributed (C2, $\mathrm{C} 3, \mathrm{C} 4, \mathrm{C} 5, \mathrm{C} 7, \mathrm{C} 10)$ and reasons to which the sire contributed (C3, C10). Of these four categories, the majority can be addressed through management, which was implicated in $67.5 \%$ of the known deaths, followed by reasons to which the dam contributed, which accounted for $42.7 \%$ of deaths. Causes with a genetic basis and to which the sire contributed, were responsible for $29.9 \%$ and $23.1 \%$ mortalities respectively. 
Table 4 Relative importance of various causes of kid mortalities from birth to weaning and calculated mortality rate due to each cause

\begin{tabular}{|c|c|c|c|c|}
\hline Code & Cause & $\begin{array}{c}\text { Number of } \\
\text { deaths } \\
(\mathrm{n}=2018)\end{array}$ & $\begin{array}{l}\text { \% Contribution } \\
\text { of each cause }^{a}\end{array}$ & $\begin{array}{l}\text { Calculated mortality } \\
\text { rate due to each } \\
\text { cause }^{\text {b }}\end{array}$ \\
\hline C1 & Predators & 235 & 39.1 & 4.5 \\
\hline C2 & $\begin{array}{l}\text { Distended teats / thick teats / udder } \\
\text { problems (blue udder) }\end{array}$ & 21 & 3.5 & 0.4 \\
\hline C3 & $\begin{array}{l}\text { Kid born prematurely / small, weak kid / } \\
\text { kid needed help with suckling }\end{array}$ & 112 & 18.6 & 2.1 \\
\hline C4 & Doe had no / little milk & 41 & 6.8 & 0.8 \\
\hline C5 & Doe abandoned kid & 41 & 6.8 & 0.8 \\
\hline C6 & Illness & 36 & 6.0 & 0.7 \\
\hline C7 & Doe died & 15 & 2.5 & 0.3 \\
\hline C8 & $\begin{array}{l}\text { Accidents (Drowned or stuck in feeding } \\
\text { or water troughs, etc.) }\end{array}$ & 35 & 5.8 & 0.7 \\
\hline C9 & Rain and cold & 32 & 5.3 & 0.6 \\
\hline C10 & Deformed kids & 27 & 4.5 & 0.5 \\
\hline C11 & Stuck in vegetation & 6 & 1.0 & 0.1 \\
\hline \multirow[t]{2}{*}{ C20 } & Cause of death unknown & 1417 & & \\
\hline & Total & & 100 & 11.5 \\
\hline
\end{tabular}

\footnotetext{
${ }^{a}$ Each cause expressed as number of deaths due to the specific cause relative to the number of deaths with known causes (e.g. for Predators = 235/601).

${ }^{\mathrm{b}}$ Calculated mortality rate due to each cause (expressed as number of kids that died per 100 kids born alive).
}

In sheep, extensive research proved that the largest proportion of lamb mortalities occurred at birth or during the first three days following birth (Alexander, 1984; Haughey, 1989; Rowland et al., 1992). There was general agreement among authors that many of these lamb mortalities could be avoided by improvements in the management and feeding of the lambing flock. It is rare for the death of the lamb to occur prior to the start of parturition; the generally accepted incidence of ovine antenatal deaths is about $2 \%$ (Haughey, 1991). Survival of the live-born lamb depends mainly on its ability to withstand environmental stress, cold and starvation. The results of two studies, the first investigating causes of lamb mortality in the United Kingdom (Wiener et al., 1983) and the second kid mortality, as perceived by Angora goat farmers in South Africa (Terblanché, 1988), indicated that the major causes of mortality can be categorised under the starvation / mismothering / exposure (SME) syndrome. SME is discussed fully by Haughey (1991). Mortalities due to "weakly lambs" and "drought, cold exposure and weak kids" were categorised as SMEdeaths in these studies.

South African workers identified mismothering as a major cause of deaths from three days to weaning (Haughey, 1991; Cloete, 1992). Neuro-hormonal factors control the induction of maternal behaviour and the formation of the selective doe-lamb bond (Keverne et al., 1992). It is clear that maternal behaviour in the doe is induced by signals from the vagina and cervix during labour. Maternal and neonatal behaviour in goats are similar to that of sheep (Blauvelt, 1954; Klopfer, 1971). However, according to Alexander et al. (1974), goats appear less likely than sheep to reject one of twins, while sheep are also considered as followers and goats are hiders (Alexander, 1988). According to the behaviour studies of Sambraus \& Wittmann (1993), the interval between the birth of the first and second kids in triplet-bearing does averaged 15 minutes and that between the birth of the second and third kid, six minutes. They also recorded that 98\% of kids did not attempt to suck any doe other than their own mother and that the average time from parturition to first suckling was 35 minutes for first-born kids and 51 minutes for subsequent kids. 
Table 5 Causes of kid mortality in the different studs, expressed as a percentage of all mortalities, including those due to unknown causes

\begin{tabular}{|c|c|c|c|c|c|c|c|c|c|c|c|c|c|c|c|}
\hline \multirow{2}{*}{ Stud } & \multirow{2}{*}{$\begin{array}{l}\text { Kids } \\
\text { born }\end{array}$} & \multirow{2}{*}{$\begin{array}{l}\text { Kids } \\
\text { died }\end{array}$} & \multirow{2}{*}{$\begin{array}{c}\text { Mortality } \\
\text { rate (\%) }\end{array}$} & \multicolumn{12}{|c|}{ Percentage of deaths resulting from: } \\
\hline & & & & Predators & $\begin{array}{c}\text { Udder } \\
\text { problems }\end{array}$ & $\begin{array}{l}\text { Weak } \\
\text { kids }\end{array}$ & $\begin{array}{l}\text { Little } \\
\text { milk }\end{array}$ & $\begin{array}{l}\text { Discarded } \\
\text { kids }\end{array}$ & Illness & $\begin{array}{l}\text { Doe } \\
\text { died }\end{array}$ & Accident & $\begin{array}{l}\text { Rain } \\
\text { cold }\end{array}$ & $\begin{array}{l}\text { Deformed } \\
\text { kids }\end{array}$ & Stuck & $\begin{array}{l}\text { Unknown } \\
\text { cause }\end{array}$ \\
\hline 1 & 833 & 25 & 3.0 & 28.0 & 0.0 & 0.0 & 0.0 & 0.0 & 12.0 & 0.0 & 4.0 & 16.0 & 4.0 & 4.0 & 32.0 \\
\hline 2 & 2055 & 273 & 13.3 & 3.3 & 0.7 & 6.2 & 1.8 & 2.2 & 1.1 & 0.0 & 2.6 & 5.1 & 0.7 & 0.0 & 76.2 \\
\hline 3 & 1542 & 177 & 11.5 & 4.5 & 0.0 & 5.6 & 2.3 & 1.1 & 0.6 & 0.0 & 0.6 & 0.0 & 1.1 & 0.0 & 84.2 \\
\hline 4 & 1168 & 108 & 9.2 & 4.6 & 0.0 & 0.0 & 0.0 & 0.0 & 6.5 & 0.0 & 0.9 & 0.0 & 0.9 & 0.9 & 86.1 \\
\hline 5 & 2506 & 378 & 15.1 & 20.9 & 2.6 & 12.4 & 6.9 & 4.2 & 2.4 & 1.9 & 0.5 & 1.6 & 2.4 & 0.3 & 43.9 \\
\hline 6 & 1140 & 95 & 8.3 & 2.1 & 1.1 & 9.5 & 1.1 & 9.5 & 3.2 & 0.0 & 0.0 & 0.0 & 1.1 & 2.1 & 70.5 \\
\hline 7 & 666 & 114 & 17.1 & 27.2 & 0.9 & 1.8 & 1.8 & 0.0 & 0.0 & 0.0 & 0.9 & 0.0 & 0.0 & 0.0 & 67.5 \\
\hline 8 & 1017 & 164 & 16.1 & 25.6 & 1.8 & 6.7 & 1.8 & 2.4 & 0.0 & 1.2 & 0.6 & 0.6 & 0.0 & 0.6 & 58.5 \\
\hline 9 & 3752 & 367 & 9.8 & 0.0 & 1.1 & 0.5 & 0.0 & 0.0 & 1.1 & 1.1 & 2.7 & 0.8 & 1.6 & 0.0 & 91.0 \\
\hline 10 & 172 & 18 & 10.5 & 5.6 & 0.0 & 0.0 & 0.0 & 0.0 & 0.0 & 0.0 & 11.1 & 0.0 & 0.0 & 0.0 & 83.3 \\
\hline 11 & 1515 & 166 & 11.0 & 28.9 & 0.0 & 7.8 & 0.0 & 1.2 & 1.8 & 0.0 & 2.4 & 0.0 & 1.2 & 0.0 & 56.6 \\
\hline 12 & 1168 & 133 & 11.4 & 2.3 & 0.0 & 0.8 & 0.0 & 1.5 & 2.3 & 1.5 & 3.8 & 3.0 & 2.3 & 0.0 & 82.7 \\
\hline
\end{tabular}


If the doe has been observed straining for more than one hour without apparent progress in the birth process, assistance should be provided. Once the kids are delivered, it is important to ensure that the dam has the opportunity to groom them. As well as providing essential stimulation for the kids, it helps in establishing the mother-kid bond; grooming for 5 - 10 minutes is usually adequate for acceptance. According to Smith (1986), there is a critical period of about two hours after birth during which the doe must be exposed to her kid if she is to accept it. It is also important that the kids feed within an hour or two of birth. As with sheep, newborn goats that are too weak to suck from their mothers should be fed by stomach-tube until they have gained sufficient strength to suck on their own.

The relative importance of the various factors associated with pre-weaning mortality in kids varies between the different studs, as presented in Table 5. Differences in recording contributed largely to this, as is evident from the difference in percentage of unknown deaths among the studs.

Over the five-year period from 2000 to 2004, a total of 1995 kids (23 kids out of the 2018 kids that died had unknown dams), born from 1662 does, died between birth and weaning age. Of these does, 1381 only lost one kid, while 236 does lost two kids, 38 lost three and seven does lost four kids. In $56 \%$ of the cases with known causes of kid mortality, the does lost two or more kids due to the same reason. The most important causes here were does abandoning their kids and does with thick teats and udder problems. This indicates that these problems will occur repeatedly in the same does. Does experiencing these kinds of problems should preferably be culled.

Rather large variation in mortality rate of kids born to different sires within a specific flock was observed (Table 6). Overall, mortality rate ranged from zero to $50 \%$ among different sires that had at least 10 progeny within a specific year. Causes of kid mortality of progeny born to different sires within the same stud also varied considerably, as is evident from Table 7. When considering the two causes of death to which the sire could contribute, small, weak kids varied from $0 \%$ to $40 \%$ among sires in Stud 5 , while deformed lambs ranged from $0 \%$ to $14.3 \%$. For instance, Sire 7 lost $27.3 \%$ kids as a result of them being small and weak and $9.1 \%$ kids were deformed. Since these causes have a genetic background, they should be taken into consideration during the selection of breeding sires.

Table 6 Variation in mortality rate among sires in the different studs (2000 to 2004)

\begin{tabular}{ccc}
\hline Stud & $\begin{array}{c}\text { Minimum mortality rate } \\
\text { per sire (\%) }\end{array}$ & $\begin{array}{c}\text { Maximum mortality rate per } \\
\text { sire (\%) }\end{array}$ \\
\hline 1 & 0 & 10.0 \\
2 & 2.1 & 45.0 \\
3 & 0 & 40.0 \\
4 & 3.6 & 17.4 \\
5 & 0 & 50.0 \\
6 & 0 & 26.1 \\
7 & 0 & 42.9 \\
8 & 0 & 41.7 \\
9 & 0 & 20.4 \\
10 & 0 & 10.0 \\
11 & 0 & 28.6 \\
12 & 0 & 25.0
\end{tabular}


Table 7 Causes of kid mortality of progeny born to different sires in Stud 5

\begin{tabular}{ccccc}
\hline \multirow{2}{*}{ Sire } & \multirow{2}{*}{ Kids born* } & Mortality rate (\%) & \multicolumn{2}{c}{ Percentage of deaths resulting from: } \\
\cline { 4 - 5 } & & & Weak kids & Deformed kids \\
\hline 1 & 18 & 27.8 & 40.0 & 0.0 \\
2 & 13 & 30.8 & 0.0 & 0.0 \\
3 & 16 & 50.0 & 25.0 & 0.0 \\
4 & 66 & 13.6 & 11.1 & 11.1 \\
5 & 37 & 18.9 & 28.6 & 0.0 \\
6 & 30 & 26.7 & 12.5 & 0.0 \\
7 & 37 & 29.7 & 27.3 & 9.1 \\
8 & 24 & 29.2 & 28.6 & 14.3 \\
9 & 23 & 26.1 & 33.3 & 0.0 \\
10 & 31 & 22.6 & 0.0 & 0.0 \\
\hline
\end{tabular}

* Only sires with more than $10 \%$ mortality included.

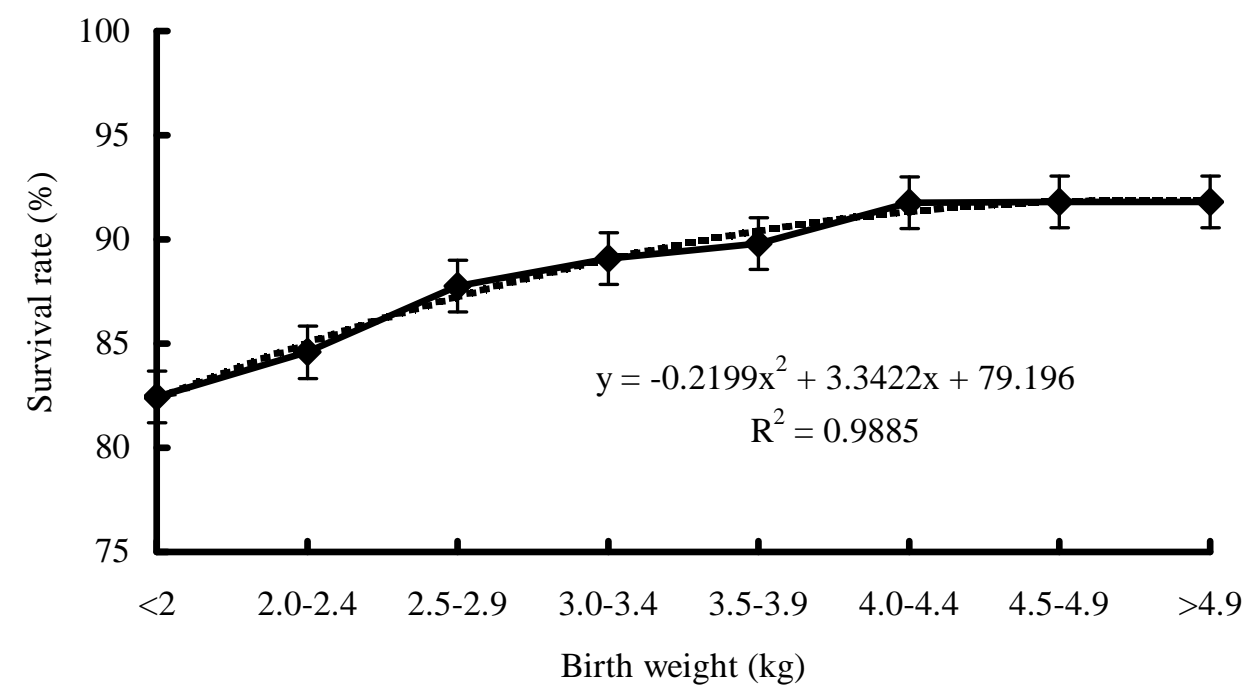

Figure 1 Relationship between survival rate and birth weight in Angora kids.

Birth weight of the kid had a significant influence on pre-weaning mortality rate. In this study, singleborn kids had the highest survival rate $(89.0 \pm 0.36 \%)$ followed by twin-born (86.1 $\pm 0.49 \%)$ and triplet-born (78.3 $\pm 2.34 \%)$ kids. The relationship between survival rate and birth weight is depicted in Figure 1 


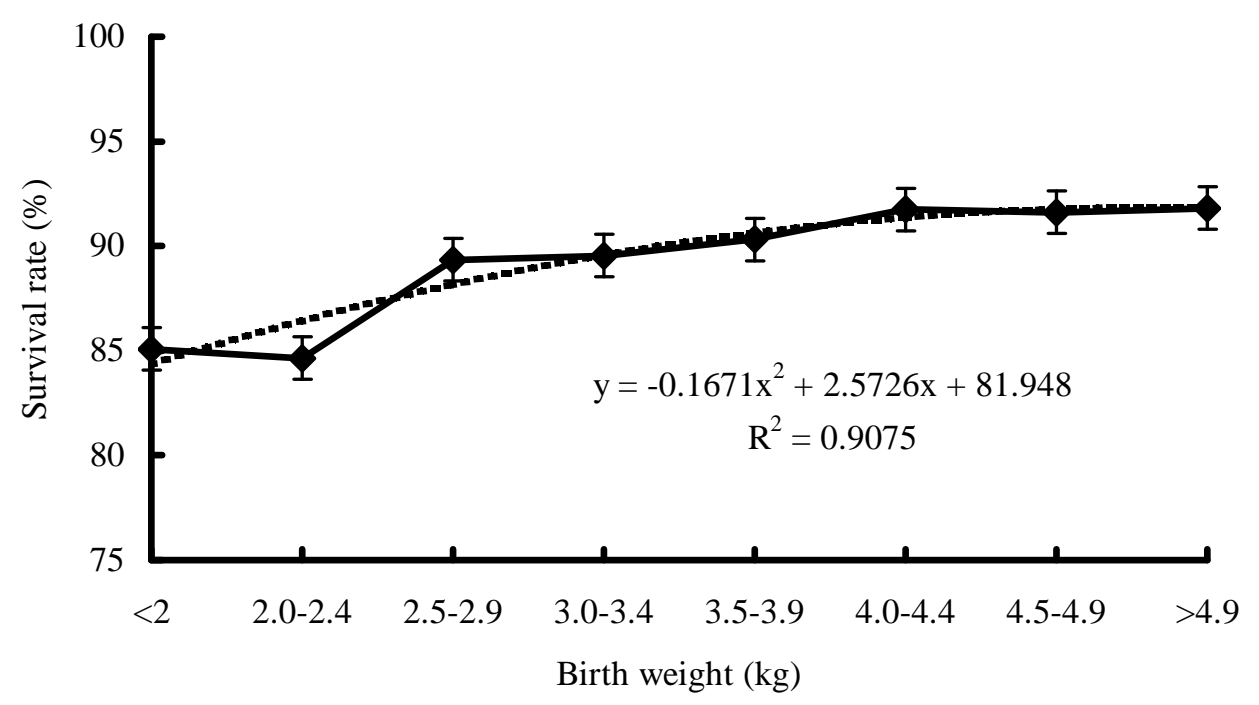

Figure 2 Relationship between survival rate and birth weight in single-born Angora kids.

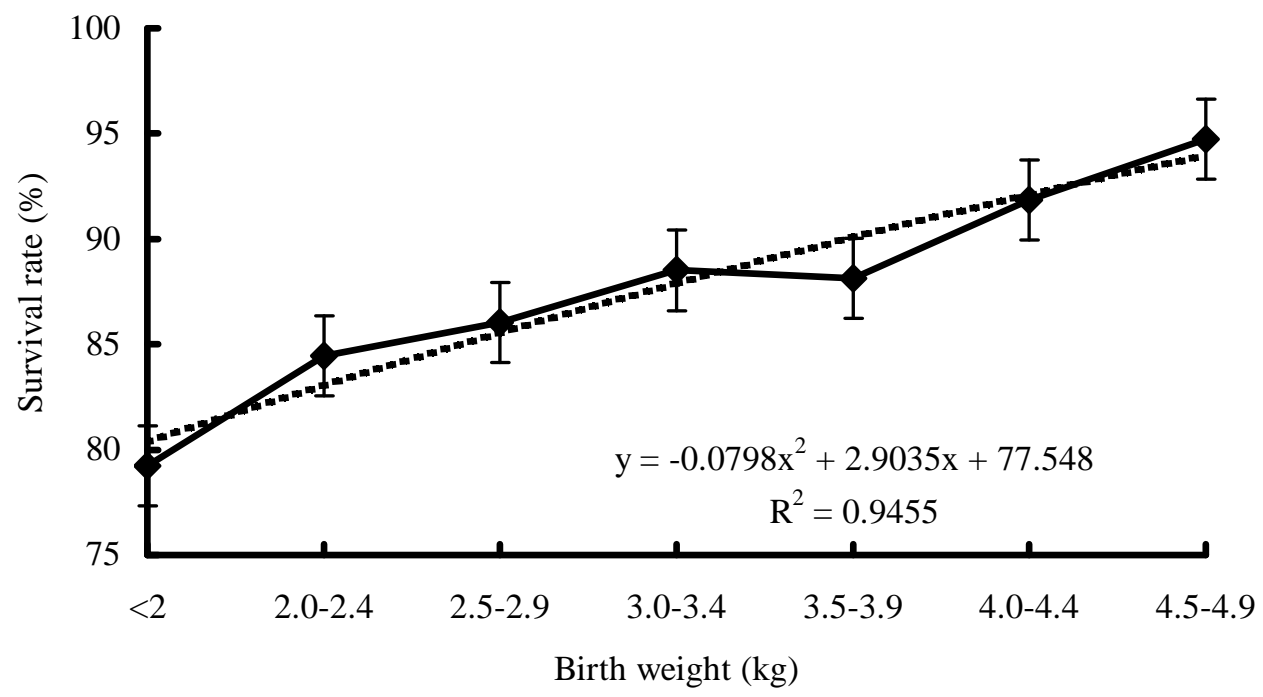

Figure 3 Relationship between survival rate and birth weight in twin-born Angora kids.

for all kids born, while the corresponding curves for single and twin-born kids are depicted in Figures 2 and 3, respectively. These findings are supported by those of Husain et al. (1995), who reported an increased survivability of kids with an increase in birth weight and milk yield of their dams. Single kids also had a higher survival rate than twin kids.

A review article by Alexander (1984) noted that mortality in sheep is typically related to birth weight by a U-shaped curve. Mortality is likely to be lowest at a weight of between 3 and $5 \mathrm{~kg}$, depending on breed and age of doe. According to Gordon (1996), lambs at both low and high birth weights may be at a disadvantage. In the one case, it would be because the lamb's energy resources may not be adequate and in 
the other case because of difficulties during the birth process. Management practices should obviously be aimed at ensuring that all lambs are as close as possible to the optimum birth weight for the breed in question. Multiple births usually have the disadvantage of lower than optimum birth weights and it is obviously beneficial for does to be separated during the final trimester of pregnancy and fed according to the number of lambs they carry.

Van der Westhuizen (1980) reported that the relationship between birth weight and mortality rate in Angora goats is more curvi-linear than U-shaped. This was confirmed in this study, where kids at the lower end of the range had lower survival rates.

\section{Conclusions}

Losses due to predators account for more than twice the number of losses than the next important cause of kid mortalities and it is important that a concerted effort be made to prevent these losses. The second most important aspect, namely the combination of udder problems, does with too little milk or does that abandon their kids, should be addressed by culling those does with distended teats or udder problems and does with too little milk, if the latter is not a major problem in the specific stud. Suitable feeding practices during the third trimester of pregnancy and first part of lactation could address the problem of does with too little milk, if this is a general problem in the stud. Furthermore, diseases could be largely prevented by the application of a suitable inoculation and drenching programme for the does and kids. Small, unthrifty kids and deformed kids have a genetic basis and should be addressed by avoiding the repeated use of sires that produced an above average number of such kids. Sons of such sires should also not be selected as breeding parents. If a large number of small, weak kids are born in the stud, a regular supplementary feeding programme during the third trimester of pregnancy should be implemented. As low birth weights are also linked to higher mortality rates, such feeding practices would also increase birth weights of kids and thereby survival rate.

\section{Acknowledgements}

The author wishes to convey her sincere appreciation to all people who participated in the project and to Mohair South Africa for funding the project.

\section{References}

Alexander, G., 1984. Constraints to lamb survival. In: Reproduction in Sheep. Eds Lindsay, D.R. \& Pearce, D.T., Australian Academy of Science, Canberra, Australia.

Alexander, G., 1988. What makes a good mother? Components and comparative aspects of maternal behaviour in ungulates. In: (12th ed.). Proc. Aust. Soc. Anim. Prod. 17, 25-41.

Alexander, G., Signoret, J.P. \& Hafez, E.S.E., 1974. Sexual and maternal behaviour. In: Reproduction in Farm Animals $3^{\text {rd }}$ ed., Ed. Hafez, E.S.E., Lea and Febiger, Philadelphia. pp. 222-254.

Awemu, E.M., Nwakalor, L.N. \& Abubakar, B.Y., 1999. Environmental influences on preweaning mortality and reproductive performance of Red Sokoto does. Small Rumin. Res. 34, 161-165.

Blauvelt, H., 1954. Dynamics of the mother-newborn relationship in goats. In: Group Processes; Transactions of the First Conference. Ed. Schaffner, B., Macy Foundation, New York. pp. 221-258.

Cloete, S.W.P., 1992. Observations on litter size, parturition and maternal behaviour in relation to lamb mortality in fecund Dormer and South African Mutton Merino ewes. S. Afr. J. Anim. Sci. 22, 241-221.

Dwyer, C.M., 2008. The welfare of the neonatal lamb. Small Rumin. Res. 76, 31-41.

Everett-Hincks, J.M. \& Dodds, K.G., 2008. Management of maternal-offspring behavior to improve lamb survival in easy care sheep systems. J. Anim. Sci. 86 (14 Suppl.), 259-270.

Geyer, A.C., 1998. Strategiese beplanning en risikobestuur vir ekstensiewe Angorabokboerdery in die Karoo. Ph.D-thesis, University of the Orange Free State, Bloemfontein, South Africa.

Gordon, I., 1996. Controlled Reproduction in Sheep and Goats. CAB International, University Press, Cambridge, UK. pp. 273.

Haughey, K.G., 1989. Studies on causes of perinatal lamb mortality in the Western Cape and the pelvic dimensions of ewes relative to their lifetime rearing performance. Department of Agriculture and Water Supply, Winter Rainfall Region, Elsenburg, South Africa.

Haughey, K.G., 1991. Perinatal lamb mortality - its investigation, causes and control. J. S. Afr. Vet. Ass. 62, 
78-91.

Husain, S.S., Horst, P. \& Islam, A.B.M.M., 1995. Effect of different factors on pre-weaning survivability of Black Bengal kids. Small Rumin. Res. 18, 1-5.

Jordan, D.J. \& Le Feuvre, A.S., 1989. The extent and cause of perinatal lamb mortality in three flocks of Merino sheep. Aust. Vet. J. 66, 198-201.

Keverne, E.B., Kendrick, K.M. \& Da Costa, A.P., 1992. Maternal behaviour in sheep. Report: Institute of Animal Physiology and Genetics Research (1990-1991), Cambridge. pp. 138-139.

Klopfer, P.H., 1971. Mother love: what turns it on? Scientific American 59, 404-407.

Mandal, A., Prasad, H., Kumar, A., Roy, R. \& Sharma, N., 2007. Factors associated with lamb mortalities in Muzaffarnagari sheep. Small Rumin. Res. 71, 273-279.

Morris, C.A., Hickey, S.M. \& Clarke, J.N., 2000. Genetic and environmental factors affecting lamb survival at birth through to weaning. N. Z. J. Agric. Res. 43, 515-524.

Mukasa-Mugerwa, E., Lahlou-Kassi, A., Anindo, D., Rege, J.E.O., Tembely, S., Tibbo, M. \& Baker, R.L., 2000. Between and within breed variation in lamb survival and the risk factors associated with major causes of mortality in indigenous Horro and Menz sheep in Ethiopia. Small Rumin. Res. 37, 1-12.

Perez-Razo, M.A., Sanchez, F. \& Meza, C., 1998. Factors affecting kid survival in five goat breeds. Can. J. Anim. Sci. 78, 407-411.

Rook, J.S., Scholman, G., Wing-Proctor, S. \& Shea, S., 1990. Diagnosis and control of neonatal losses in sheep. Advances Sheep Goat Med. 6 (3), 531-562.

Rowland, J.P., Salman, M.D., Kimberling, C.V., Schweitzer, D.J. \& Keefe, T.J., 1992. Epidemiologic factors involved in perinatal lamb mortality on four range sheep operations. Am. J. Vet. Res. 53, 262-267.

Sambraus, H.H. \& Wittman, M., 1993. Parturition and sucking behaviour in goats. Kleinviehzuchter 41, 582-584.

Smith, M.C., 1986. Perparturient care of the doe. In: Current Therapy in Theriogenology. Eds. Morrow, D.A. \& Saunders, W.B., Philadelphia, USA. pp. 589-590.

Snyman, M.A., 2010. Influence of body weight, age and management system on reproduction of South African Angora goat does. S. Afr. J. Anim. Sci. 40, 41-53.

Southey, B.R., Rodriguez-Zas, S.L. \& Leymaster, K.A., 2004. Competing risks analysis of lamb mortality in a terminal sire composite population. J. Anim. Sci. 82, 2892-2899.

Terblanché, E.leF., 1988. 'n Ondersoek na Angorabokboerdery in die Republiek van Suid-Afrika. BKB, Port Elizabeth.

Turkson, P.K., 2003. Lamb and kid mortality in village flocks in the coastal savanna zone of Ghana. Trop. Anim. Hlth Prod. 35 (6), 477-490.

Turkson, P.K. \& Sualisu, M., 2005. Risk factors for lamb mortality in Sahelian sheep on a breeding station in Ghana. Trop. Anim. Hlth Prod. 37 (1), 49-64.

Van der Westhuizen, J.M., 1980. Perinatal mortality in the Angora goat. The Angora Goat and Mohair J. 22 (1), 19-87.

Wiener, G., Woolliams, C. \& Macleod, N.S.M., 1983. The effects of breed, breeding system and other factors on lamb mortality. I. Causes of death and effects on the incidence of losses. J. Agric. Sci., Camb. 100, 539-551. 